\title{
The development of green infrastructure through optimization of water resources carrying capacity in Yogyakarta urban area
}

\author{
Widodo Brontowiyono ${ }^{1, *}$, Dhandhun Wacano $^{1}$, and Ribut Lupiyanto ${ }^{1}$ \\ ${ }^{1}$ Environmental Engineering Program, Universitas Islam Indonesia, Jln. Kaliurang KM 14.5, 55584 Yogyakarta, Indonesia \\ ${ }^{2}$ Center for Environmental Study, Universitas Islam Indonesia, Jln. Kaliurang KM 14.5, 55584 Yogyakarta, Indonesia
}

\begin{abstract}
The development of Yogyakarta Urban Area has spread to its surroundings. As a result, water resources carrying capacity and environmental problems are worsening. Rainwater harvesting (RWH) development as part of green infrastructure is one of the important methods to increase water resources carrying capacity. Relating to the problem, this research was conducted in Yogyakarta Urban Area. The study was a combination of field research and studio analysis. The field study measured the settlement's physical parameters and surveyed the community's socio-economic and cultural aspects. According to the physical and economic analysis based on CBR, the recommended models of water resource conservation infrastructure were absorption well/1.10; conservation pond/4.53; open space/7.47; and green space/3.59. Meanwhile, rainwater reservoir was not suggested because the CBR value was only 0.18
\end{abstract}

\section{Introduction}

The United Nations has predicted that three out of five people in the world would live in urban areas by 2030 [3]. Meanwhile, in Yogyakarta, the urbanization rate has increased significantly. The very limited land extent has forced the urbanization in Yogyakarta to spread to the area of Sleman Regency and Bantul Regency.

In Sleman, for example, the growing number of housing complexes is closely related to Yogyakarta's status as a study destination that is supported by the development of related business sectors. There are about $60 \%$ of university campuses in Sleman, and $63 \%$ of the students predictably come from other areas outside Yogyakarta Province. As a result, the demand for housing is increasing. In fact, the construction of housing property in Yogyakarta Province has reached $71 \%$ - the highest percentage of all - while $26 \%$ of the construction is used for commercial property and the remaining comprises industrial and conference construction [1].

Meanwhile, [13] forecasted that in 2030s the agricultural land in Sleman, Yogyakarta, and Bantul would be used up for settlement if there was no control. In addition, the development of settlement has caused such problem as a decrease in water resources carrying capacity. Therefore, this paper was aimed to recommend the models and strategies for settlement planning and management using the concept of green settlement to strengthen the water resources carrying capacity.

\section{Research method}

The research was conducted in Yogyakarta Urban Area. This area was chosen based on the complexity of area dynamics and potential degradation of environmental carrying capacity, particularly the water resources. The study was conducted by combining field research and studio analysis. The field research was done to measure the settlements' physical parameters and to survey the community's social, economic, and cultural aspects.

The social and economic data were gathered in a primary as well as secondary way. The secondary data came from reports or official sources from related boards while the primary data were collected through semistructured interview using questionnaire. The research population was the households living in Yogyakarta Urban Area. The respondents were the householders that were determined using proportional cluster random sampling. The settlement cluster was divided into settlement areas in elite estate, medium estate, small estate, hamlet, and a mix of hamlet and estate. The total number of samples was 100 householders [4,8].

The settlements' physical data were collected from field survey, semi-structured interview using questionnaire, as well as in-depth interview. The field survey and questionnaire were conducted according to the settlement clusters that consist of elite estate, medium estate, small estate, hamlet, and a mix of hamlet and estate.

\section{Results and discussion}

\subsection{Economic feasibility of green infrastructure} models

* Corresponding author: widodo.bronto@uii.ac.id 
Green settlement infrastructure (hereinafter referred to as green infrastructure) has several technical models in its implementation that can be an alternative. As recommended in the first year's report, the models include rainwater absorption well, rainwater reservoir, polder, open space, conservation pond, and vegetation. In the context of Yogyakarta Urban Area, all these types of infrastructure can be implemented.

According to the critical level of water resources, Yogyakarta Urban Area is categorized as an anthropogenic critical area. It is an area that has critical water resources because the high population growth has exceeded the water supply, and it is found mostly in urban areas with high population density and limited land availability.

The following analysis described the economic feasibility of each implementation model. The analysis was conducted for a period of 20 years, which was estimated as the average age of storage model with $16 \%$ discount level.

The first model is rainwater absorption well. The shape of absorption well is similar to that of ordinary well, yet the function is the opposite because absorption well is used for collecting rainwater from the roof or absorbing runoff into the ground. Various shapes and dimensions of absorption well have been widely used because there is no standard size. Technically, an accurate calculation should be conducted in order to reach maximum absorption with minimum construction cost. The calculation of construction cost in this study was based on the concept model from [10] with a diameter of $100 \mathrm{~cm}$ and a depth of $50 \mathrm{~cm}$ above the groundwater table. The prediction of construction cost is presented in Table 1.

Table 1. Estimation of construction cost for rainwater absorption well based on existing market price

\begin{tabular}{|l|r|r|r|}
\hline Component & \multicolumn{1}{|c|}{$\begin{array}{c}\text { Quantity and } \\
\text { unit }\end{array}$} & $\begin{array}{c}\text { Price/ unit } \\
\text { IDR } \\
10^{3}\end{array}$ & $\begin{array}{c}\text { Total cost } \\
\text { IDR } \\
10^{3}\end{array}$ \\
\hline Betonbuizen & 5 piece & 85 & 425 \\
\hline Cement & 2 sack & 50 & 100 \\
\hline Sand & $1 / 4$ pickup truck & 120 & 120 \\
\hline Gutter & $20 \mathrm{~m}$ & 8 & 160 \\
\hline Pipe & 4 length & 80 & 320 \\
\hline Worker & 2 days & 60 & 240 \\
\hline \multicolumn{3}{|c|}{ Total } & 1,365 \\
\hline
\end{tabular}

According to Table 1, the total cost of absorption well construction was Rp 1,365,000.00. The cost included the expense for equipment, materials, and workers, and the value was based on the average market price in the research area. Besides the construction cost, the land price and maintenance cost were also considered. To make a realistic consideration, the minimum need for land was calculated based on the size of well section of $1 \mathrm{~m} 2$ that equaled Rp 500,000.00. Meanwhile, the maintenance was predicted to be done every 5 years of usage in the form of well emptying to normalize the absorption capability; the emptying process required $\mathrm{Rp} 150,000.00$.

The following calculation was conducted for the benefit, which was merely based on the effect of absorption well on the increase in groundwater table.
Other benefit variables were difficult to predict economically because of the extensive land size and time required. [6] showed that the existence of absorption well in Yogyakarta has raised the level of groundwater table by 0.282 meter per year. Since the research area was the same, the aforementioned value was used to estimate the benefit of absorption well in this study. For this research, the benefit value was calculated only by comparing the increase at the beginning and end of the study for three months. Therefore, the total volume increase was the volume of water use during the three months added by the difference value at the end of the research.

The economic value was based on the average pipedwater (PDAM) bill for every cubic meter, which was Rp 3,000 per cubic meter in the research area. The average use of water per capita for domestic need reached 100 liters per day, in which the average number of household members in the research area was 4 people. Therefore, the total volume of the increase in groundwater table was 4 people $\times 0.1 \mathrm{~m}^{3} /$ day $\times 90$ days $+(3.14 \times 0.5 \times 0.5) \times 0.282$ $=36.221 \mathrm{~m}^{3}$. On the other hand, the ability to absorb rainwater also depends on the rainfall.

The calculated value would be reached when the average rainfall was $800.66 \mathrm{~mm}$. Since the average rainfall in the research area was $2133.33 \mathrm{~mm}$ [9], it was predicted that the total volume of the increase in groundwater table was $(2133.33 / 800.6) \times 36.221 \times 3=$ $144.59 \mathrm{~m}^{3}$ or as much as $\mathrm{Rp} 433,770.00$. Table 2 illustrates the result of cost-benefit ratio analysis based on the aforementioned values.

Table 2. Analysis of cost-benefit ratio for absorption well construction

\begin{tabular}{|l|r|}
\hline \multicolumn{1}{|c|}{ Parameter } & \multicolumn{1}{|c|}{$\begin{array}{c}\text { Total value } \\
\text { IDR } \\
\end{array}$} \\
\hline Net Cost (15\%) & $10^{3}$ \\
\hline Net Benefit (15\%) & $1,917.344$ \\
\hline Net Present Value (NPV) & $2,546.317$ \\
\hline Cost-Benefit Ratio & 628.973 \\
\hline
\end{tabular}

The obtained net benefit was found higher than the net cost and the difference as much as Rp 628,973.00 was considered as the value of net benefit based on the present value (NPV). This positive NPV indicated that the costbenefit ratio would reach more than 1 , which was proven by the value of in the table. Therefore, it is concluded that, economically, absorption well was feasible to implement in the research area. The next analysis was to determine the payback period.

Graphically, this value could be determined using Fig. 1 , in which the payback period is located on the intersection between the net cost and net benefit (breakeven point). The graph shows that the payback period of absorption well would occur in the $7^{\text {th }}$ year of the project. Therefore, starting from the $7^{\text {th }}$ year, the community would enjoy the net benefit of the use of absorption well. The payback period would occur before the project period ended; this means that absorption well was feasible. 


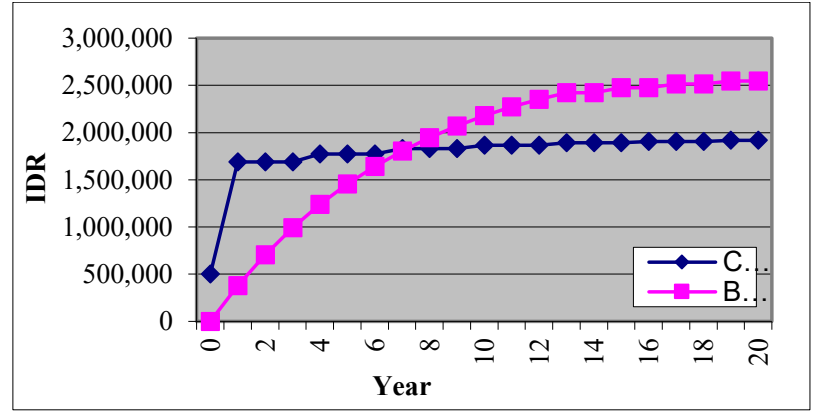

Fig.1. Graph of payback period for absorption well

The second model is rainwater reservoir $(\mathrm{PAH})$ whose function is limited to storage only. The position can be above the building, on the ground, or under the ground. It is easier to use if the reservoir is located above the building, and it is more suitable for urban area with limited land, but the construction cost is high. It is more efficient when installed on the ground, but it requires land availability. The last position does not depend on land availability, but the construction cost and pumping cost are higher. This research analyzed on-the-ground reservoir because the land availability in the research area made it possible, and it was predicted that the cost would be more efficient.

The shape of rainwater reservoir can be cylindrical, rectangular, globular, or others. Considering the construction effectiveness and efficiency, this research chose the rectangular shape to be analyzed. Similar to that of absorption well, the cost component comprised the construction, land, and maintenance cost. The reservoir construction consisted of the cost of materials, workers, and equipment for water treatment. The collected rainwater can go through a certain treatment to be used as drinking water. In this study, a filter was chosen to keep water clean and to anticipate turbidity, which was more efficient than the regular use of alum. Table 3 illustrates the cost details.

Table 3. Estimation of Construction Cost for Rainwater Reservoir Based on Existing Market Price

\begin{tabular}{|l|r|r|r|}
\hline Component & Quantity and unit & $\begin{array}{c}\text { Price } \\
\text { IDR } \\
10^{3}\end{array}$ & $\begin{array}{c}\text { Total } \\
\text { IDR } \\
10^{3}\end{array}$ \\
\hline Construction: & & & \\
- cement & 20 sack & 50 & 1,000 \\
- brick & 4000 piece & 0.425 & 1,700 \\
- sand & 1 pickup truck & 660 & 660 \\
- faucet & 2 piece & 15 & 40 \\
- iron & 20 length & 28 & 560 \\
- filter & $20 \mathrm{~m}^{2}$ & 7.5 & 150 \\
\hline Worker & 4 days & 25 & 400 \\
\hline \multicolumn{4}{|c|}{ Total } \\
\hline
\end{tabular}

During the operation, the cost would be added by the maintenance cost to empty the reservoir in order to keep it clean at the end of the dry season. The emptying cost per year was $\mathrm{Rp} 50,000.00$. The total cost was then compared to the benefit based on the economic value of rainwater that could be used during the dry season. It was assumed that in the dry season only rainwater reservoir was used.

In this study, the capacity of rainwater reservoir was based on the need during the dry season, which was 221 days $\mathrm{x} 4$ people $\mathrm{x} 0.1 \mathrm{~m}^{3}=88.4 \mathrm{~m}^{3}$. Therefore, the benefit was $88.4 \times \operatorname{Rp~} 3,000=\operatorname{Rp} 265,320.00$. This value was similar to the affordable price of piped water in the research area.

The result of cost and benefit calculation is presented in Table 4. It can be seen that the cost value far exceeded the benefit, so the NPV was negative and the CBR was below 1. This indicated that in the research area the construction of rainwater reservoir was not feasible. This was influenced by the limitation of capacity benefit that only works during the dry season, the need for large reservoir, and the high construction cost due to the size and land value. For houses that could allow the construction of reservoir on the top floor, the cost could be minimized, especially for the land value and ease of use.

Table 4. Result of cost-benefit ratio analysis for rainwater reservoir

\begin{tabular}{|l|r|}
\hline \multicolumn{1}{|c|}{ Parameter } & \multicolumn{1}{|c|}{$\begin{array}{c}\text { Total value } \\
\text { IDR } \\
\end{array}$} \\
\hline Net Cost (15\%) & $10^{3}$ \\
\hline Net Benefit (15\%) & $4,326.295$ \\
\hline Net Present Value (NPV) & $1,660.232$ \\
\hline Cost-Benefit Ratio & $-2,666.263$ \\
\hline
\end{tabular}

The unfeasibility was also supported by the result of payback period and IRR analysis. Fig. 2 shows that the payback period was far above the project age, even unlimited, while when the trial-and-error process using up to $0 \%$ discount was conducted, the NPV still could not give positive value.

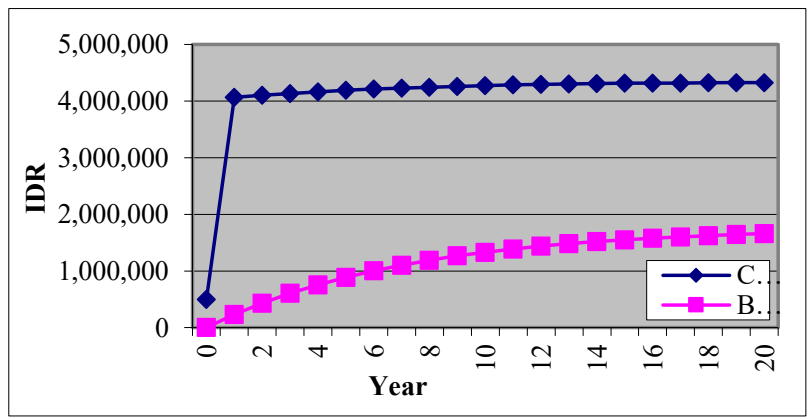

Fig. 2. Graph of payback period for rainwater reservoir

The next rainwater harvesting infrastructure that can be managed is conservation pond. In general, it is similar to a fish pond, but it is designed to have a frame on the surroundings while the bottom is only soil to ensure water absorption. The analysis of economic feasibility in this study was conducted for each square meter of the pond because there was no standard size. The construction cost included the dredging and making of surrounding frame that were estimated to spend $\mathrm{Rp} 480,000.00$ with the land value of $\mathrm{Rp} 500,000.00$ in Table 5 . 
Table 5. Estimation of initial investment value for conservation pond

\begin{tabular}{|l|r|r|r|}
\hline Component & $\begin{array}{l}\text { Quantity } \\
\text { and unit }\end{array}$ & $\begin{array}{c}\text { Price } \\
\text { IDR } \\
10^{3}\end{array}$ & $\begin{array}{c}\text { Total } \\
\text { IDR } \\
10^{3}\end{array}$ \\
\hline Worker & 4 in 2 days & 60 & 480 \\
\hline Land & $1 \mathrm{~m}^{2}$ & 500 & 500 \\
\hline \multicolumn{3}{|c|}{ Total } & 980 \\
\hline
\end{tabular}

The maintenance would be conducted by dredging the bottom to reduce sedimentation every 3 years for $\mathrm{Rp}$ $50,000.00$. The measurable benefit was similar to that of absorption well, which was the effect on groundwater table. [12] described that the pitch, which is closest in model to this type of pond, had the ability to absorb 70\% rainfall for every square meter of the pond. By comparing with the benefit of absorption well, the economic benefit of conservation pond was $\mathrm{Rp} 303,639.00$ per year.

This benefit value far exceeded the cost, which is shown in Table 6. The NPV value was positive and the CBR value was 1.33 . This value could increase if the pond was also used as a fish pond.

Table 6. result of cost-benefit ratio analysis for conservation pond

\begin{tabular}{|l|r|}
\hline \multicolumn{1}{|c|}{ Parameter } & \multicolumn{2}{|c|}{$\begin{array}{c}\text { Total value } \\
\text { IDR } \\
10^{3}\end{array}$} \\
\hline Net Cost (15\%) & 994.118 \\
\hline Net Benefit (15\%) & $1,900.871$ \\
\hline Net Present Value (NPV) & 906.683 \\
\hline Cost-Benefit Ratio & 1.91 \\
\hline
\end{tabular}

Based on this value, it was found that the payback period occurred in the $9^{\text {th }}$ year in Fig 3. All the analysis results showed that the conservation pond was feasible to manage.

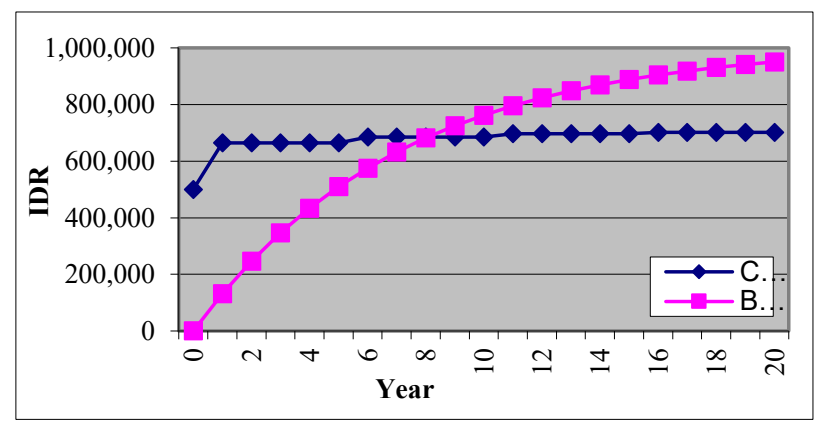

Fig. 3. Payback period for the construction of conservation pond

Another infrastructure to consider in rainwater harvesting is open space. The cost for its construction was very low, only $\mathrm{Rp} 500,000.00$ per square meter of land and $\mathrm{Rp} 188,500.00$ for building the foundation surrounding the land that showed in Table 7.
Table 7. Estimation of construction cost for open space per square meter

\begin{tabular}{|c|r|r|r|}
\hline Component & \multicolumn{1}{|c|}{$\begin{array}{c}\text { Quantity } \\
\text { and unit }\end{array}$} & $\begin{array}{c}\text { Price } \\
\text { IDR } \\
10^{3}\end{array}$ & \multicolumn{1}{c|}{$\begin{array}{c}\text { Total } \\
\text { IDR } \\
10^{3}\end{array}$} \\
\hline Construction: & 1 sack & 50 & 50 \\
• cement & $\begin{array}{r}\text { 100 piece } \\
\text { - brick }\end{array}$ & 0.425 & 42.5 \\
• sand & 0.1 pickup truck & 660 & 66 \\
\hline Worker & 1 in 0.5 day & 60 & 30.5 \\
\hline \multicolumn{3}{|r|}{ Total } & 188.5 \\
\hline
\end{tabular}

The calculation of benefit was the same as that of conservation pond, which was based on the absorption ability of the open space and the influence of absorption well on the groundwater table. [2] noted that an open space with sandy soil in the research area would result in a maximum of $15 \%$ runoff that could reduce approximately $50 \%$ evaporation and absorb around $35 \%$ of water. The value gave an economic benefit as much as Rp 151,820.00 (1 cubic meter of water equaled the price of piped water as much as Rp. 3,000.00). The analysis of cost-benefit resulted in positive NPV and the value of CBR reached 7.47, which was far above 1 can see in Table 8.

Table 8. Result of cost-benefit ratio analysis for open space construction (per $\mathrm{m}^{2}$ )

\begin{tabular}{|l|r|}
\hline \multicolumn{1}{|c|}{ Parameter } & $\begin{array}{c}\text { Total value } \\
\text { IDR } \\
\end{array}$ \\
& $10^{3}$ \\
\hline Net Cost (15\%) & 701.625 \\
\hline Net Benefit (15\%) & 950.439 \\
\hline Net Present Value (NPV) & 248.814 \\
\hline Cost-Benefit Ratio & 1.36 \\
\hline
\end{tabular}

The value of CBR was quite high and even resulted in a payback period in the 8th year in Fig. 4.

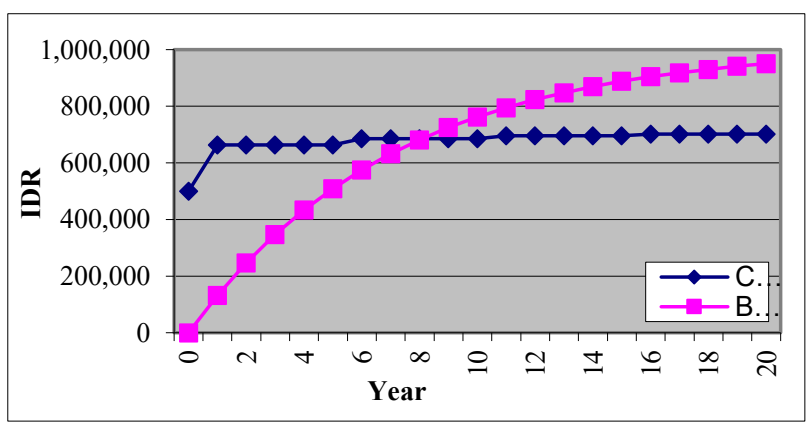

Fig. 4. Payback period for open space management

The last infrastructure to be economically analyzed is green space (RTH). The analysis was conducted for one plant, especially productive plant. Table 9 shows the estimation of investment value to manage vegetation; one plant needs 4 square meter of land. U.S. Forest Services [2] explained that productive vegetation could absorb maximum $25 \%$ runoff. 
Table 9. Estimation of initial investment value for green space construction per $\mathrm{m}^{2}$

\begin{tabular}{|l|r|r|r|}
\hline Component & $\begin{array}{l}\text { Quantity } \\
\text { and unit }\end{array}$ & \multicolumn{1}{|c|}{$\begin{array}{c}\text { Price } \\
\text { IDR } \\
10^{3}\end{array}$} & $\begin{array}{l}\text { Total } \\
\text { IDR } \\
10^{3}\end{array}$ \\
\hline Seedling & $1 \mathrm{plant}$ & 25 & 25 \\
\hline Fertilizer & $2 \mathrm{~kg}$ & 10 & 10 \\
\hline Land & $1 \mathrm{~m}^{2}$ & 500 & 500 \\
\hline \multicolumn{3}{|c|}{ Total } & 535 \\
\hline
\end{tabular}

Therefore, when subtracted by $50 \%$ evaporation level, the $25 \%$ absorption capability would be equal to $\mathrm{Rp}$ $108,443.00$. Another benefit was the plant's product that could be estimated to worth Rp 50,000.00 per plant, and this could be obtained after 3 years. Based on this value, the NPV was positive and CBP was above 1 in Table 10.

Table 10. Result of cost-benefit ratio analysis for green space construction per plant

\begin{tabular}{|l|r|}
\hline \multicolumn{1}{|c|}{ Parameter } & \multicolumn{2}{|c|}{$\begin{array}{c}\text { Total value } \\
\text { IDR } \\
\end{array}$} \\
\hline Net Cost (15\%) & 530.436 \\
\hline Net Benefit (15\%) & 755.666 \\
\hline Net Present Value (NPV) & 225.230 \\
\hline Cost-Benefit Ratio & 1.43 \\
\hline
\end{tabular}

The payback period was obtained in the 8th year of the project that can seen in Fig. 5.

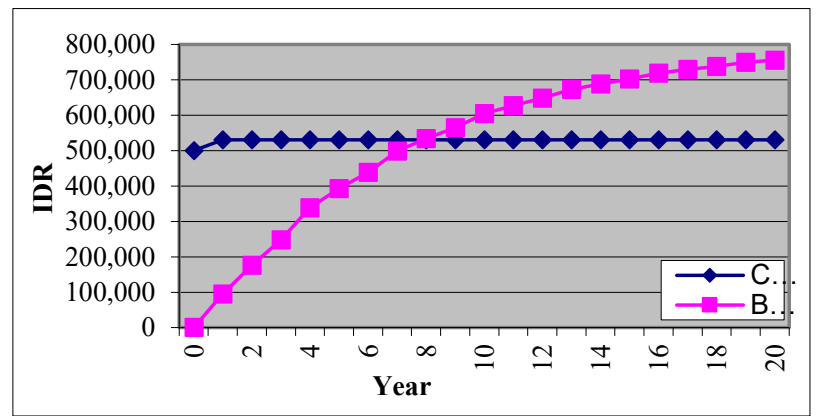

Fig. 5. Payback period for green space construction

Based on the analysis result, a recommendation priority could be determined for the construction of green infrastructure in Table 11. The priority showed the cost effectiveness of each infrastructure type. All the types of infrastructure were prioritized because the benefit value used in the calculation was very limited, so it had not yet involved indirect benefit and benefit for other areas.

In order of priority, the types of infrastructure that could be conservation pond, absorption well, greend space, open space, and rainwater reservoir respectively. Besides the aforementioned general assumption, the specific assumption was about the generalization of research area characteristics, such as the same physiographical condition, economic value of water, rainfall, land availability, and economic condition. This assumption did not apply to specific areas, such as naturally critical area; in this type of area, the priority could not be implemented.
Table 11. Priority of green infrastructure construction

\begin{tabular}{|c|r|c|c|l|c|}
\hline TI & $\begin{array}{c}\text { NPV } \\
\text { IDR } \\
10^{3}\end{array}$ & CBR & $\begin{array}{c}\text { PBP } \\
\text { (year) }\end{array}$ & EF & P \\
\hline Aw & 628.973 & 1.33 & 7 & F & II \\
Rr & $-2,666.263$ & 0.38 & $>20$ & Un-F & V \\
Cp & 906.683 & 1.91 & 5 & F & I \\
Os & 248.814 & 1.36 & 8 & F & IV \\
Gs & 225.230 & 1.43 & 8 & F & III \\
\hline
\end{tabular}

Note:

TI : type of infrastructure; PBP: pay back period; EF: Economic Feasibility; F: feasible; Aw : Absorption Well; Rr : Rainwater Reservoir; Cp: Conservation Pond; Os: Open Space; Gs: Green Space

\subsection{Social feasibility of the green infrastructure models}

The construction of green infrastructure is required even at the level of households. Therefore, a feasibility that is merely based on profit-loss analysis is not enough to make a participative policy. The community's ability to pay and willingness to manage also need to be considered. The community's ability can be analyzed using ATP analysis while their willingness can be determined using WTP analysis [11]. That can be seen in Table 12 .

Table 12. Respondent's ownership of green infrastructure

\begin{tabular}{|l|c|c|}
\hline \multicolumn{1}{|c|}{ Ownership } & Quantity & Percentage \\
\hline Own (at least 1 type) & 32 & 40 \\
\hline Not own at all & 48 & 60 \\
\hline
\end{tabular}

The critical area of research was in Yogyakarta Urban Area with dense settlement land use. This condition was strongly assumed as influencing the level of green infrastructure ownership. Table 13 illustrates that only $40 \%$ of the respondents in the surplus area owned green infrastructure. Besides the need for water, the environment's physical condition, especially the land, also became a factor that influenced the ownership level and type of green infrastructure as shown in Table 13.

Table 13. Respondents' ownership of each type of green infrastructure

\begin{tabular}{l|c|c|c|c|}
\hline \multirow{2}{*}{ TI } & \multicolumn{2}{|c|}{ Own } & \multicolumn{2}{c|}{ Not own } \\
\cline { 2 - 5 } & quantity & $\%$ & quantity & $\%$ \\
\hline $\mathrm{Aw}$ & 4 & 5 & 76 & 95 \\
\hline $\mathrm{Rr}$ & 0 & 0 & 80 & 100 \\
\hline $\mathrm{Cp}$ & 0 & 0 & 80 & 100 \\
\hline $\mathrm{Gs}$ & 16 & 20 & 64 & 80 \\
\hline Os & 16 & 20 & 64 & 80 \\
\hline Note:
\end{tabular}

TI : type of infrastructure; Aw : Absorption Well; Rr : Rainwater Reservoir; Cp: Conservation Pond; Os: Open Space; Gs: Green Space

In the research area, none of the types of green infrastructure was dominant although there were only three types, which were $5 \%$ ownership of absorption well and $20 \%$ ownership of green space or open space. Green space and open space can naturally appear although ideally they still need management and almost always exist if a household has a yard. This is supported by the 
data in Table 13 showing the types of green infrastructure that required better management. They were absorption well, rainwater reservoir, and conservation pond that was more varied and less owned. Table 14 shows other evidence of the encouragement of respondents who owned those types of green infrastructure.

Table 14. Respondents' support to manage green infrastructure

\begin{tabular}{|l|c|c|}
\hline \multicolumn{1}{|c|}{ Source of support } & Quantity & $\%$ \\
\hline Awareness & 20 & 62.5 \\
\hline Government & 12 & 37.5 \\
\hline Inadvertence & 0 & 0 \\
\hline
\end{tabular}

Awareness had dominated the support to manage green infrastructure by $62.5 \%$. This is directly proportional to the level of water demand. Meanwhile, none of the respondents in the anthropogenic critical area had green infrastructure without support. This was because of the limited land availability for natural vegetation and open space as well as due to the better level of education normally owned by urban community.

The management of green infrastructure is influenced not only by the physical environment as previously explained but also by the economic condition, especially the ability to manage. The respondents' economic conditions in the three areas were similarly good although there were a variety of levels. The easiest method to identify the economic level is by using poverty indicators. According to [7], one of the methods to determine the poverty level is based on the level of equivalent-to-rice household expense, in which the minimum limit is equivalent to $320 \mathrm{~kg} / \mathrm{capita} / \mathrm{year}$ (standard of Central Bureau of Statistics).

Based on the macro-economic condition of the three areas, which was also similar, the average value of poverty limit equivalent to the price of rice as much as $\mathrm{Rp}$ $4,000 / \mathrm{kg}$ for household expense was Rp $1,280,000 /$ capita/year. On the average, the households in the research area consisted of 4 members, so the poverty limit for household expense was Rp 5,120,000/year or approximately Rp. 427,000/month.

In the research area, the average economic condition was good because it was above the poverty line in Table 15 . Only $20 \%$ of the respondents were poor because the research area had non-agricultural activities that were more developed to earn a living.

Table 15. Respondent's Economic Condition

\begin{tabular}{|c|c|c|c|c|c|}
\hline $\begin{array}{c}\text { Expense/ } \\
\text { month } \\
\text { IDR } \\
10^{3}\end{array}$ & Quantity & $\%$ & $\begin{array}{l}\text { Poverty } \\
\text { category }\end{array}$ & Quantity & $\%$ \\
\hline$\leq 427$ & 3 & 15 & Poor & 4 & 20 \\
\hline $427-800$ & 4 & 20 & Not poor & 16 & 80 \\
\hline $800-1,200$ & 10 & 50 & & & \\
\hline$\geq 1,200$ & 3 & 15 & & & \\
\hline
\end{tabular}

In general, the condition indicated that the respondents had the ability to manage green infrastructure because most of the cost was only for initial construction. Table
15 illustrates the quantitative value of respondents' ability (ATP) to manage green infrastructure. The ATP in the research area was Rp. 1,500,000 due to the good economic condition and life demand. Based on this value, the types of green infrastructure that could be immediately managed by considering the cost were absorption well, conservation pond, green space, or open space.

Apart from the ATP analysis result, a WTP analysis was also conducted to strengthen the social feasibility analysis see Table 16. WTP analysis was carried out to identify the perception of green infrastructure implementation in the form of respondents' willingness level. The benefit of rainwater for primary need is mostly obtained indirectly, and there is a negative character of rainwater. Therefore, it should be considered that besides the economic feasibility, WTP also influenced respondents' perception of rainwater.

Table 16. respondents' perception of rainwater

\begin{tabular}{|l|c|c|}
\hline \multicolumn{1}{|c|}{ Type of perception } & Quantity & Percentage \\
\hline Should be collected & 48 & 60 \\
\hline Should be overlooked & 12 & 15 \\
\hline Should be discarded & 20 & 25 \\
\hline
\end{tabular}

Amount $60 \%$ of the community in the research area perceived that rainwater should be harvested, $15 \%$ thought to overlook rainwater, and $25 \%$ believed that it should be disposed of. The perception to collect rainwater is affected by water demand as well as education level. Meanwhile, the opinion that rainwater should be ignored or immediately discarded was supported by the thought that rainwater is usually a source of disease and disaster without considering that the real cause is management. Even if this was already understood, some showed skepticism about whether the management had been optimum. That can be seen in Table 17.

Table 17. Respondents' willingness to manage green infrastructure

\begin{tabular}{|l|c|c|}
\hline \multicolumn{1}{|c|}{ Willingness } & Quantity & Percentage \\
\hline Willing & 15 & 75 \\
\hline Not willing & 5 & 25 \\
\hline
\end{tabular}

These levels of perception were used to direct the following question about the respondents' willingness to manage green infrastructure. The $75 \%$ WTP in the research area showed a positive condition for green infrastructure management in Table 17. It indicated that some respondents perceived to neglect rainwater while some others were willing to collect it because they were aware of its benefit. Therefore, the effort to convince the community becomes the key factor to achieve wider acceptance see Table 18. 
Table 18. Socio-economic feasibility of green infrastructure

\begin{tabular}{|c|c|c|c|c|}
\hline TI & $\begin{array}{c}\text { Cost benefit } \\
\text { analysis }\end{array}$ & ATP & WTP & $\begin{array}{c}\text { Socio- } \\
\text { economic } \\
\text { feasibility }\end{array}$ \\
\hline Aw & + & + & + & + \\
\hline Rr* & - & - & + & - \\
\hline Cp & + & + & + & + \\
\hline Gs & + & + & + & + \\
\hline Os & + & + & + & + \\
\hline
\end{tabular}

Note:

+ : feasible; * : not a priority of recommendation; - : unfeasible

TI : type of infrastructure; Aw : Absorption Well; Rr : Rainwater Reservoir; Cp: Conservation Pond; Os: Open Space; Gs: Green Space

\section{Conclusion}

The result of Cost-Benefit, ATP, and WTP analyses could be used to identify the socio-economic feasibility of green infrastructure management. All the types of green infrastructure in the research area were feasible, except the rainwater reservoir due to the high investment cost and limited land availability. In addition, physically, the research area had good absorption ability, so it would be more effective and proven as feasible to manage absorption well, conservation pond, green space, or open space. This area had limited land availability and good economic condition; therefore, the management of green infrastructure would be more effective if absorption well was prioritized because of its flexibility towards land availability and due to its higher benefit value.

\section{References}

1. Z. Arifin, Identification of factors relating to the growth of housing business in Sleman-in bahasa, LOGIKA R.J., 4, (2007).

2. C. Asdak, Hydrology and watershed management, (2007).

3. M. Baiquni, Unsustainable development: a critical reflection of Indonesian development, Trans Media, (2002).

4. S. Faisal, Social research formats: foundations and applications, (Rajawali Press 1995).

5. Kadariah, Evaluation of economic analysis projects, first edition, (LPFE-UI, 1999).

6. R. Lupiyanto, 2009, Designing a green settlement along the city river: a case of Tegal Panggung, (BKPRN, 2009).

7. L. Muta'ali, Regional Analysis Engineering, (FGEUGM, 2000).

8. M. Singarimbun, Survey research methods, (LP3ES, 1995)

9. B. Sulistiono, Bambang, Selecting the best rainfall distribution in a designed flood analysis using synthetic unit hydrograph of gamma I, Teknisia J. 10, (2005).
10. Sunjoto, Optimization of rainwater absorption well as one of the efforts to prevent seawater intrusion, hydarulica and Hidrologi, (1988).

11. O. Tamim, Evaluation of public transport fares and analysis of Ability to Pay and Willingness to Pay in DKI Jakarta, Jurnal Transportasi Jurusan Teknik Sipil-ITB 1, (1999).

12. D. K. Todd, Groundwater Hydrology 2nd edition, (John Wiley, 1980).

13. W. Brontowiyono, Vulnerability Water Resources Mapping, International SURED Integrated Water Management in Urban Environment, DAAD-Uni Karlsruhe-UKI, (2005). 